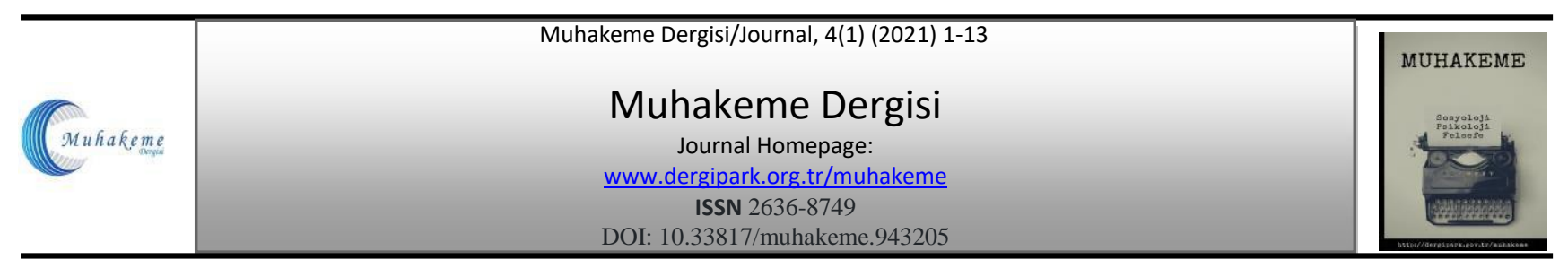

\title{
Çocuklarda Yalan Söyleme Davranışı ve Gelişim Süreçleri
}

\author{
Muhammed Şükrü AYDIN ${ }^{1}$
}

\section{ÖZET}

Yalan söyleme davranışı, bir başkasında niyetli olarak yanlış kanılar oluşturma çabasıdır. Literatürde yalan söyleme davranışlarının gelişiminin incelendiği araştırmaların büyük çoğunluğunun okul öncesi dönemdeki çocuklara yoğunlaştığı görülmektedir. Yalan söyleme davranışlarının okul öncesi dönemden itibaren nasıl gelişim gösterdiği ve çeşitli sosyal, kültürel, bilișsel etmenlerin yalan söyleme üzerindeki etkisine yönelik araştırmalar ise son yirmi yılda artış göstermiştir. Ancak Türkiye'deki araştırmaların yalan söyleme davranışları konusunda henüz başlangıç aşamasında olduğu görülmektedir. Bu nedenle, mevcut derleme çalışmasında yalan söyleme davranışlarının gelişimiyle ilgili araştırmalara değinilerek bu davranışlarının doğasının anlaşılması ve Türkçe literatürde görülen eksiklik giderilmeye çalışılmıştır. Ayrıca eksik kalan noktalar üzerinden ileride yapılacak araştırmalar için öneriler sunulmuştur.

Anahtar Kelimeler: Yalan söyleme davranışı, yalan söylemenin gelişimi, erken çocukluk, sosyal-bilişsel gelişim.

\section{Lie-Telling Behavior and Developmental Processes in Children}

\begin{abstract}
Lie-telling behavior is an attempt to constitute false beliefs intentionally in another person. It is known that most of the studies examining the development of lie-telling behaviors focus on preschool children in the literature. Studies about the developmental process on lie-telling behaviors in preschool children, and the effects of various social, cultural and cognitive factors on these behaviors have increased in the last two decades. However, it is seen that studies on lie-telling behaviors are at the beginning stage in Turkey. Therefore, in the present paper, by referring to the studies on the development of lie-telling behaviors, the nature of these behaviors was tried to be understood and to eliminate the limitations seen in the Turkish literature. In addition, suggestions were made for future research based on the lacking points.
\end{abstract}

Keywords: Lie-telling behavior, development of lying, early childhood, social-cognitive development.

\section{GíRiş}

Yalan kavramı, en genel haliyle "gerçek olmayan ifade" şeklinde ifade edilse de göründüğünden çok daha karmaşıktır. Psikoloji literatürü incelendiğinde, yalan tanımlarının araştırmacılara göre farklılaştı̆g görülmektedir. Goffman'a (1967) göre yalanda önemli olan başkalarında yanlış kanı oluşturmaktır. Ruffman, Olson, Ash ve Keenan (1993) ise yalan söyleyen kişinin istendik ve kasıttı olarak bu ifadelere başvurmasının yalan için kritik olduğunu vurgulamışlardır. Bu açıklamalar doğrultusunda bir ifadenin yalan olarak değerlendirilmesinde, "niyetli" olarak başkalarında "yanlış kanılar oluşturma girişiminin" önemli olduğu görülmektedir.

İnsanlar yalanı genel olarak olumsuz olarak görmektedir ancak araştırmalar yalanı "ortaya çıkardığı sonuçlara", "önemine" ve "hangi niyetle söylendiğine" göre değerlendirmenin önemine dikkat çekmektedir (DePaulo, Kashy, Kirkendol, Wyer ve Epstein, 1996). Başkalarını korumak, üzülmelerini

\footnotetext{
${ }^{1}$ Araştırma Görevlisi, İstanbul Üniversitesi, Edebiyat Fakültesi, Psikoloji Bölümü, msukruaydin@hotmail.com
} 
önlemek ve iyi oluşlarını devam ettirmek gibi amaçlarla söylenen yalanlar insanlar tarafından makul bulunmaktadır çünkü sonuçları açısından başkasına faydası vardır. Ancak kişinin kendi çıkarına hizmet eden, ciddi anlamda olumsuz sonuçlar doğuran ya da başkasına zarar verme niyetiyle söylenen yalanlar ise olumsuz olarak değerlendirilmektedir. Araştırmalarda yalan tanımlamaları ve yalanın türleri hakkında çeşitli görüşler öne sürülmekle birlikte; yalanın ortaya çıkardığı sonuçlar açısından bakıldığında yalanın "başkasına zarar verme" ve "yarar sağlama" şeklinde iki boyutunun ön planda olduğu görülmektedir (Aydın, 2020). Bununla birlikte, araştırmalarda vurgulanan hangi niyetle yalan söylendiği meselesinin de önem taşıdığı açıktır. Literatürdeki açıklamalar doğrultusunda (Aydın, 2020), yalanın iki türü üzerinden devam etmek uygun görülmüş ve çalışmanın devamında "prososyal yalan" ve "olumsuz yalan" olarak isimlendirilerek bu yalan türlerinin gelişimine değinilmiştir. Yurt dışında gerçekleştirilen bazı çalışmalarda antisosyal yalan şeklinde ifade edilen yalanların Türkçe'de aynı durumu karşılamaması nedeniyle literatürde antisosyal olarak nitelendirilen bu tür yalanlar mevcut çalışmada olumsuz yalan olarak değerlendirilmiştir.

\section{Çocuklarda Yalan Söyleme Davranışının Gelişimi}

Yalan söyleme davranışını çocukluk döneminde sistematik ve deneysel bir şekilde incelemek aslında birçok zorluğu da beraberinde getirmektedir. Çocukların yalan söyleme davranışları söz konusu olduğunda ebeveynlere çocuklarının ne sıklıkla yalan söyledikleri sorularak çıkarımlarda bulunulmuştur. Ancak bu tür bir yaklaşımın doğruluğu, ebeveynlerin çocuklarının hangi yalanlarına odaklanarak rapor ettikleri, yalanların gerçekten farkına varıp varmadıkları gibi hususların açık olmaması nedeniyle eleştiriye açıktır. Daha yakın zamanda gerçekleştirilen araştırmalar ise doğrudan çocuk gözlemlerini içermeye başlamıştır. $\mathrm{Bu}$ sayede araştırmacılar, yalan söyleme davranışlarının doğasını anlayabilmek için bu tür davranışların ne zaman ortaya çıktığını, hangi faktörlerden etkilendiğini ve nasıl bir gelişimsel süreci takip ettiğini ele almaya başlamışlardır (Talwar ve Crossman, 2011).

Doğal gözlemlerden edinilen bulgulara göre, bazı çocukların iki yaşından itibaren yalan söylemeye başladıkları, okul öncesi dönemin sonuna kadar ise neredeyse bütün çocukların yalan söyleyebildikleri anlaşılmaktadır (Wilson, Smith ve Ross, 2003). Araştırmalar erken yaşlarda görülen yalanların genellikle başkalarına zarar vermeyen, kolaylıkla ortaya çıkan türde olduklarını göstermektedir. İlerleyen yaşlarda çocukların sosyal normlara ve toplumsal kurallara uymaya başladıkça, yalanların sosyal ilişkileri sürdürmek için yararlı bir strateji olduğu ve başkalarına fayda sağlamak için söylenmeye başladığı da bilinmektedir. Talwar ve Lee (2008) bu gözlem ve bulgulardan yola çıkarak, çocukların kendi çıkarlarına hizmet eden yalanlarının zamanla olgunlaşarak daha az kendilerini koruyacak türden olmaya başladığına ve bu nedenle çocukların yalan söyleme davranışlarının gelişimini ele alırken yalanın türünü (prososyal-olumsuz gibi) göz önünde bulundurmak gerektiğine dikkat çekmişlerdir.

Çocukların iki yaşına doğru konuşmaya başlamalarıyla yalanı değerlendirmek mümkün hale gelince; yalan söyleme davranışının erken yaşlardaki gelişimi ve çocukların hangi nedenlerle yalan söylediklerine yönelik araştırmalar da artmıştır. Çocuklarda erken dönemde görülen ve kendi menfaatlerini gözetme amacıyla söyledikleri yalanların, benlik kavramı ve zihinsel durumlara yönelik anlayışla birlikte ortaya çıktığı belirtilmiştir (Talwar ve Crossman, 2011). Buna göre, çocuğun doğru olmayan bir şey yaptığına dair kendilik anlayışının yanı sıra kendi eyleminin diğer insanlar tarafından bilinmeyeceğinin farkındalığı şeklinde iki beceri önemli görünmektedir. Benlik kavramı 15-24 aylar arasında (Lewis, Sullivan, Stanger ve Weiss, 1989); zihin kuramı becerisinin en basit düzeyinin ise ilk olarak 2 yaş civarında yerleşmeye başladığı (Moll ve Tomasello, 2007) yönündeki açıklamalar da bu görüşü destekler niteliktedir.

Çocuklarda yalan söyleme davranışlarının ne zaman başladığına yönelik literatürde birçok araştırma mevcuttur. Evans ve Lee'nin (2013) ilk yalanların ne zaman görülmeye başladığına yönelik 2-3 yaş grubu çocuklarla yaptığı çalışmada, 3 yaşındaki çocukların önemli bir kısmının yalan söyleme becerisi gösterdikleri, 2 yaşındakilerinse sadece dörtte birinde yalanın ortaya çıktığı bulunmuştur. Ayrıca 2 ve 3 yaşları arasında çocukların yalan söyleme eğilimlerinde ciddi bir artış görüldüğü de belirtilmiştir. Çocuklarda yalan söyleme davranışı konusunda öncü bir isim olan Ekman (2016) da 2-3 yaş arasındaki çocukların yalan söyleme konusunda yeterince iyi olmadıklarını belirterek, yalan söyleyen çocukların genellikle cezadan kaçınma ve kendini koruma amaçlı bu davranışlara başvurduklarını ifade 
etmektedir. Talwar ve Crossman'ın (2011) yapmış oldukları gözden geçirme çalışmasında da çocukların iki buçuk yaş civarında kendini korumaya yönelik yalan söylediklerini, üç yaşındaki çocukların bir kısmı ile dört yaşındaki çocuklarının ise neredeyse hepsinin bir yanlışı gizlemek ve olası cezalardan kaçmak için yalana başvurduklarını raporlamışlardır.

Okul öncesi dönemdeki çocuklarda yalan söyleme davranışlarını değerlendirmek üzere son yirmi yılda doğrudan müdahaleli gözlem yöntemi kullanılması bu davranışların gelişimini incelemede erken yaş dönemlerini ele almaya imkân tanımıştır. $\mathrm{Bu}$ konuda yürütülen çalışmalarda en sık kullanılan görevlerden biri "cazibeye karşı koyma paradigması (temptation resistance paradigm)" (Talwar ve Lee, 2002a) olmuştur. Bu görevde çocuklarla bir tahmin oyunu oynanmakta ve üç doğru tahminde bulundukları takdirde kendilerine ödül verileceği söylenmektedir. Çocuklardan yüzü duvara dönük olacak şekilde oturmaları istendikten sonra araştırmacı bir oyuncak getirmekte ve çıkardığı sesten çocukların oyuncağın ne olduğunu tahmin etmeleri istenmektedir. Tahmini kolay olan iki denemeden sonra (Örn. ağlayan bebek sesi, polis arabası sireni) çocuğu zorlayan test aşamasına geçilmektedir. Araştırmacı test aşamasında, ses çıkarmayan peluş bir oyuncak seçip aynı zamanda cızırtılı melodi çalan bir müzik kutusu açmaktadır. Çocuklar tahminde bulunmadan önce araştırmacı odadan bir dakikalığına ayrılması gerektiğini ve kendisi dışarıdayken çocukların arkalarına bakmamaları gerektiğini söylemektedir. Bir dakika sonra araştırmacı kapıya yaklaşarak gürültü çıkarmakta ve ardından odaya girmektedir. Çocuklar araştırmacıya doğru cevabı verdikten sonra araştırmacı çocuklara arkalarını dönüp bakıp bakmadıklarını sorarak yalan söyleme davranışını ölçmektedir. Türkiye'deki çocukların yalan söyleme davranışlarının aynı yöntemle incelendiği bir çalışmada (Aydın, 2021), çocukların üç yaşlarına doğru kural ihlalini gizlemek amacıyla yalan söyledikleri bulunmuştur. 29-72 aylık çocuklarla yürütülen bu çalışmada, en küçük 34 aylık bir çocuğun olumsuz yalanı söylemede başarılı olduğu ve bu tür yalanların yaşla birlikte doğrusal bir artış gösterdiği sonucuna ulaşılmıştır.

Çocukların yabancılık çekmeyeceği varsayılarak ev ortamlarında söyledikleri yalanları incelemenin önemine dikkat çeken bazı araştırmacılar da olmuştur. Bunlardan biri olan Wilson ve arkadaşlarının (2003) çalışmasında, 3 ile 6 yaş aralığındaki çocukların yalan söyleme sıklıkları ev ortamında 90 dakikalık iki ayrı zaman diliminde değerlendirilmiştir. Gözlemler sonucunda, çocukların yalan söyleme sıklıklarının yaşla birlikte artış gösterdiği; en çok rastlanılan yalan söyleme nedenlerinin ise sorumluluktan kaçınma, kontrol elde etme ve kardeşine suçlamada bulunma olduğu rapor edilmiştir. Bununla birlikte, 3 yaşındaki çocukların neredeyse üçte ikisinin, 4 yaş çocuklarının ise tamamına yakınının en az bir kere yalan söylediği bulunmuştur. Başka bir çalışmada, araştırmacılar 3 ve 4 yaşlarında çocuğu bulunan 24 anneden çocuklarının evde söyledikleri yalanları kayıt altına almaları istenmiştir (Newton, Reddy ve Bull, 2000). Bu çalışmanın sonuçları da benzer şekilde çocukların yalan söyleyebildikleri ve bunu yaparken işten kaçınma ve kazanç elde etme amacının ön planda olduğunu göstermiştir. Bir başka çalışmada, iki haftalık zaman diliminde, 3-14 yaş arasındaki çocukların ev ortamlarındaki yalan söyleme davranışları bir önceki çalışmaya benzer bir şekilde annelerden günlük tutmaları istenerek gerçekleştirilmiştir (Lavoie, Leduc, Arruda, Crossman ve Talwar, 2017). Sonuçlar, çocukların ortalama iki günde bir yalan söylediklerini ve yalan söyleme sıklığının yaşla birlikte azaldığını göstermiştir. Yalan türleri açısından değerlendirildiğinde, küçük yaştaki çocukların genellikle kazanç elde etmek için ve bir işten kaçmak için yalan söyledikleri, erken ergenlik dönemindeki çocukların ise genel olarak daha az yalan söyledikleri ve söyledikleri yalan türünün önemli bir kısmının başkalarını korumak olduğu görülmüştür. Yalan türlerinde yaşa göre farklılık gösteren bu bulgu, yaş ilerledikçe çocukların toplumsal normlar ve sosyalleşme süreçlerinin de etkisiyle sosyal yönden uygun olabilecek türdeki yalana başvurdukları şeklinde yorumlanmıştır. Bu çalışmalardan elde edilen sonuçlara göre, küçük yaştaki çocukların yalanlarının kendi menfaatlerini korumak ve kazanç elde edebilmek adına söylendiği ve bu yalanların 3 yaş civarında görülmeye başlandığı ifade edilebilir.

Olumsuz yalan söyleme davranışının gelişimsel sürecine bakıldığında, doğrusal bir artış göstermediği söylenebilir. Bu tür yalanlar, ergenlik döneminde zirveye doğru çıkarken, yetişkinlikle birlikte nispeten daha düşük bir seviyeye gerilemektedir (Serota, Levine ve Boster, 2010). Yetişkinlik dönemindeki bu düşüşün nedeni olarak yetişkinlerin sosyal çevreleriyle baş etme yolu olarak kandırma ve yalan söyleme gibi stratejilere başvurmamaları gösterilebilir. Böylece yetişkinler sosyal çevrelerinde kendi saygınlıklarına zarar verecek bir eylemde bulunmamış olurlar. Yine de, okul öncesi dönemden 
yetişkinliğe uzanan boylamsal çalışmaların olmaması yalanın nasıl bir gelişimsel yol izlediği ve bunları hangi faktörlerin etkileyebileceği gibi konuları hala belirsiz kılmaktadır.

Çocukluk dönemindeki olumsuz yalanları inceleyen çalışmaların yeterli bir sayıya ulaştığı görülmektedir fakat prososyal niyetle söylenen yalanların ne zaman ortaya çıktığı ve bu tür yalanların gelişimsel süreçlerinin ele alındığı çalışmaların sınırlı olduğu söylenebilir. Aslında erken yaşlardan itibaren, çocukların başkalarına karşı iyi görünmek ve kibar olmak adına ebeveynleri tarafindan bazı ortamlarda nasıl davranmaları ve konuşmaları gerektiği öğretilmektedir. Böylece çocuklar erken dönemlerde gerçek his ve düşüncelerini saklamayı öğrenmeye başlamaktadırlar. Örneğin, dil ve konuşma becerisi normal gelişim düzeyinde olan 2 yaş civarındaki bir çocuk, bir başkasının fiziksel görünümü kötü olduğunda bunu açıkça söyleyebilir. Ancak yetişkinlerin, çocuklarının bu fikirlerini açığa çıkarmalarına yönelik engelleme girişimleri çocuk açısından bir bakıma doğruluğa karşı vurulmuş bir darbe olarak görülebilir. Çocukların daha sonra yaşanabilecek benzer yaşam olaylarında yetişkinlerin tembihlemelerine uygun bir şekilde davranmaları aslında çocukların küçük beyaz yalanlar söylemelerinin nasıl teşvik edildiğinin bir göstergesidir.

Çocukların prososyal yalanları söylemeye hangi yaşlarda başladıklarının incelendiği öncü çalışmalardan birinde, 6 yaşındaki çocukların nezaket amacıyla prososyal yalan söyleyebildikleri bulunmuştur (Gnepp ve Hess, 1986). Benzer dönemlerde Cole (1986) tarafından okul öncesi dönem çocuklarıyla yapılan bir başka çalışmada, 3-4 yaşlarındaki çocukların da prososyal yalan söyleyebildikleri bulunmuştur. Bu gibi sonuçlar, erken çocukluk dönemindeki çocukların gerçek hislerini saklayabildiklerini ve nezaket gereği yalan söylenebileceğinin anlaşıldığını akla getirmektedir. Talwar ve Lee (2002b), bu çalışmaların üzerinden yıllar geçtikten sonra 3 ile 7 yaş arasındaki çocukların prososyal yalan söyleme davranışını inceledikleri araştırmada çocukların önemli bir kısmının prososyal yalan söyleyebildiklerini ortaya koymuştur. $\mathrm{Bu}$ çalışmada yaşa göre farklılık olmadığı gösterilmiş ve 3 yaşındaki çocukların prososyal yalan söyleme becerisini kazandıkları ifade edilmiştir.

Okul öncesi dönemdeki çocukların prososyal yalan söyleme davranışlarını değerlendirmek üzere literatürde en çok kullanılan görev "hayal kırıklığına uğratan hediye paradigmasıdır (disappointing gift paradigm)" (Saarni, 1984). Bu görevde, ilk olarak yardımcı araştırmacı (A2) çocukla birlikte araştırma odasına girer ve çocuğa içerisinde çeşitli oyuncaklar bulunan kutuyu göstererek "oyunumuz bittiğinde bunlardan birini sana vereceğim, şimdi bana en çok beğendiğin ve beğenmediğin şeyi gösterir misin" diye sorarak çocukların yanıtlarını kaydeder. Bu sırada, araştırmacı (A1) uygulama odasında olmadığı için çocukların hangi hediyeyi beğendikleri ve beğenmedikleri konusunda bilgi sahibi değilmiş gibi görünmektedir. Çocukların cevapları kaydedildikten sonra A2 işi olduğu için çıkması gerektiğini söyler ve A1 odaya gelir. Çocuk ve A1 birlikte oynadıktan sonra araştırmacı "kutunun içerisinden gözü kapalı görünecek şekilde çocuğun beğenmediği oyuncağı" seçer. Araştırmac1 beğenilmeyen hediyeyi verdikten sonra çocuklara "hediyeni nasıl buldun" diye sorarak kendilerine gerçek ve yalan söyleme firsatı sunulur. Hediyeyi beğenmediğini ifade eden katılımcılar "doğru söyleyen", hediyeyi beğendiğini ifade eden katılımcılar ise "prososyal yalan söyleyen" olarak değerlendirilmektedir. Prososyal yalan söyleme davranışlarının Türkiye'de incelendiği sınırlı sayıda çalışmalardan birinde, 29-72 aylık çocukların prososyal yalan söyleme davranışları hayal kırıklığına uğratan hediye göreviyle araştırılmıştır (Aydın, 2021). Bu çalışmada prososyal yalanın en erken 32 aylık bir çocukta görüldüğü ve 29-35 aylık yaş grubundaki çocukların dörtte birinin prososyal yalan söyleyebildikleri sonucuna ulaşılmıştır. Aynı çalışmanın bulguları, büyük yaş grubundaki çocukların prososyal yalan söyleme bakımından küçüklere kıyasla daha iyi olduklarını ancak bu konuda 3, 4 ve 5 yaşlarında doğrusal bir artış olmadığını göstermiştir.

Çocuklarda yalan söyleme davranışının gelişimi konusunu özetlemek gerekirse, çocuklarda ilk olarak olumsuz yalanların ortaya çıktığı ancak bu tür yalanların ardından hem prososyal hem olumsuz yalanların birlikte gelişim gösterdiği ifade edilebilir. İlk olarak, 2-3 yaş arasındaki çocuklarda gerçek dışı açıklamalarla karşılaşmak mümkündür (Talwar ve Lee, 2008). İkinci aşamada, 3 ile 4 yaş arasında, çocuklar kendi suçlarını gizlemek için yalan söylemeye başlarlar. Aynı zamanda yine bu yaş dönemindeki çocuklarda, hayal kırıklığ yaratan hediye görevindeki gibi prososyal niyetlerle söylenen yalanlar da görülür (Talwar, Murphy ve Lee, 2007). İlk iki aşamada, çocukların kural ihlali yaptıktan sonra kendilerine yöneltilen sorulara verdikleri cevaplarla yalan söyledikleri kolaylıkla ortaya çıkabilir. Örneğin, kimsenin olmadığı odada, bir oyuncağa bakmak için arkasını dönen ama bunu yapmadığını iddia eden çocukların, oyuncağın ne olduğu sorulduğunda bunu bildiklerini ve arkalarını hiç 
dönmediklerini söylemeleri henüz basit yalan söyleme evresinde olduklarının bir göstergesidir. 7-8 yaşlarında ortaya çıkan üçüncü aşamada ise çocukların çalışmalarda kullanılan görevlerde takip (test) sorularına tutarlı cevaplar verebildikleri, bu nedenle yalanların daha profesyonel ve sistematik bir hale geldiği söylenebilir (Talwar ve Lee, 2008).

\section{Yalan Söyleme Davranışını Etkileyen Etmenler}

Görüldüğü üzere çocukların 3 yaşına kadar basit yalanlar söyledikleri ve itiraf ettikleri konusunda herhangi bir ihtilaf görünmemektedir. Ancak 3 yaşından itibaren, birçok alanda olduğu gibi yalan söyleme davranışları konusunda da çocuklarda önemli bir gelişme göze çarpmaktadır. Burada sorulması gereken soru ise dört yaşındaki çocukların neden daha iyi yalan söyleme becerisine sahip olduklarıdır. Üç yaşından sonra çocuklarda gelişimi hızlanan yönetici işlevler ve zihin kuramı gibi bilişsel becerilerin ve ilerleyen yıllarda çeşitli sosyal ve kültürel faktörlerin bu süreçte etkili olduğuna ilişkin yapılan açıklamalara ilerleyen bölümde yer verilmektedir.

\section{Bilişsel Etmenler}

Çocuğun yalan söyleyebilmesi için gerçeği baskılaması ve başkalarının kanılarını manipüle edebileceğini düşünmesi onların bazı bilişsel beceriler bakımından hazır hale gelmiş olmaları gerektiğini düşündürmektedir. Aslına bakılırsa, çocuğun yalan söyleyerek başkasını kandırması doğruyu söylemesinden daha zor bir iş gibi durmaktadır. Bu nedenle, yalan söyleme ve kandırma davranışlarında bilişsel becerilerin önemli rol oynadığı düşünülmektedir.

\section{a. Zihin Kuramı ve Yalan Söyleme Davranışı Arasındaki Bă̆lantılar}

1980'lerden itibaren, yalan söyleme davranışını araştıran çalışmaların sayısı giderek artmıştır. Aslında bu durum, zihin kuramı araştırmalarının da aynı zamanlarda başlamasıyla açıklanabilir. Zihin kuramı, diğerlerinin farklı kanı, arzu ve niyetlere sahip olabileceğinin ve diğerlerinin sahip olduğu farklı kanı, arzu ve niyetlerinin sonraki davranışlarını belirleyeceğinin anlaşılması olarak tanımlanmaktadır (Wellman, 1990). Zihin kuramı becerisi başkalarının istek, duygu, düşünce ve niyetlerine ilişkin farkındalık getirdiğinden diğer insanların nasıl davranacağına yönelik tahminde bulunmayı kolaylaştırmaktadır. Zihin kuramı çalışmalarından ortaya çıkan sonuç, çocukların 3 yaşından itibaren diğerlerinin farklı kanıları olabileceğini kavradıklarını göstermektedir (Wellman, Cross ve Watson, 2001).

Farklı kanıların anlaşılmasının, çocukların basit yalanlarına eşik atlatarak daha profesyonel ve sistematik yalan söyleme becerisi edinimlerine katk1 sağladığı söylenebilir. Şöyle ki, yalan söyleyebilmek için, yalanı söyleyen kişi karşısındaki kişinin zihnine niyetli olarak yanlış bir kanı eklemeli ve bu yanlış kanının onun sonraki davranışlarını belirleyebileceğini anlamalıdır. Hatta yalan söyleyen kişi diğerinin sahip olduğu yanlış kanının doğru kanılarından farklı olduğunu da anlayabilmelidir. Talwar, Gordon ve Lee (2007), yalana bu bakış açısıyla yaklaşarak bu becerinin özünde yatanın zihin kuramı olduğuna dikkat çekmişlerdir. Yalanın başkalarının zihninde yanlış kanılar oluşturma gerekliliğinden hareketle, çocukların yalan söyleme davranışları ile zihin kuramı becerileri arasındaki bağlantılar birçok çalışmada ele alınmıştır (Talwar ve Lee, 2002a; 2008). Üç ile beş yaş arasındaki çocuklarla çalışan Polak ve Harris (1999), yanlış kanıları anlama konusunda başarılı olan çocukların, bu beceride henüz yeterli olmayan çocuklara kıyasla daha fazla yalan söylediklerini bulmuşlardır.

Kişinin kendisini korumak ve çıkar sağlamak için söylediği yalanlarda üst düzey bir zihin kuramı anlayışının olmasına gerek olmayacağı düşünülebilir. Çocuklar yapmış oldukları kötü bir şeyi gizleme konusunda belki de çok zorlanmayabilirler. Ancak bazı yalanların daha gelişmiş zihin kuramı yeterliliğiyle desteklendiği ifade edilmiştir. Örneğin, Williams, Moore, Crossman ve Talwar'a (2016) göre prososyal yalan, yalan söylemeyi, uygun olmayan davranışın baskılanmasını (yüzünü asmak) ve uygun davranışın ortaya konulmasını (sahte bir gülümseme) gerektirir. Talwar ve Crossman'ın (2011) öne sürdükleri gelişimsel yalan modeli de benzer bir şekilde, ilk söylenen yalanların daha az zihin kuramı becerisi gerektirdiğine ve aslında doğası gereği olumsuz türde olduğuna işaret etmektedir. $\mathrm{Bu}$ 
noktadan hareketle zihin kuramı becerisinin daha gelişmiş olmasının, çocukların basit olumsuz yalanlardan ziyade daha karmaşık ve farklı türdeki yalanlar söylemesine katkı sağlayacağı söylenebilir.

\section{b. Yönetici Isşlevler ve Yalan Söyleme Arasındaki Bă̆lantılar}

Yönetici işlevler yüksek düzey bilişsel işlevleri tanımlamak amacıyla ortaya çıkmıştır ve literatürde farklı tanımlarıyla karşılaşmak mümkündür. Hughes, Graham ve Grayson (2002) yönetici işlevleri, yeni karşılaşılan ve görece zor olan görevleri gerçekleştirebilmek için gerekli olan karmaşık bilişsel süreçleri kapsayan bir terim olarak ele almışlardır. Yönetici işlevlerin bir işe başlama, dikkatin sürdürülmesi, yeni durumlara uyum sağlanması, düşüncelerin değerlendirilmesi ve eyleme başlamadan önce davranışların sonucunu düşünebilme gibi birçok alanda rol oynadığını görmek mümkündür (Miyake vd., 2001).

Yönetici işlevlerin yalan söyleme becerisi için önemli rolü olduğunu söylemek mümkündür. Başarılı bir şekilde yalan söyleyebilmek ve sonrasında bunu sürdürebilmek için, o kimsenin doğru olan bilgiyi engellemesi, yanlış bir bilgi üretmesi ve söyleyeceği yalanla ilgili belirli kısımları gerçekle çelişmeyecek şekilde hatırlaması gerekmektedir (Gombos, 2006). Bu açıdan değerlendirildiğinde, yalan söyleme davranışının görülmesinde iki önemli yönetici işlev bileşeninin rolü olduğu düşünülebilir. Bunlardan biri inhibisyon kontrolü becerisi, diğeri ise çalışma belleğidir.

Ampirik araştırmalarda bellek ve inhibisyon kontrolü gibi bilişsel süreçlerin yalan söyleme davranışlarındaki rolü incelenmiştir. Olumsuz yalan söyleme davranışı ve yönetici işlevler bileşenleri arasındaki bağlantıları inceleyen çalışmalarda her iki değişken arasında çoğunlukla pozitif yönde ilişki olduğu sonuçları mevcuttur. Örneğin, Evans, Xu ve Lee (2011), 4 yaşındaki çocuklarda daha yüksek inhibisyon kontrolü becerisinin, yalanı sürdürme ve kanıtlarla tutarlı olacak şekilde sözel ifadeler üretebilme yetenekleri ile ilişkili olduğunu bulmuştur. Carlson, Moses ve Hix (1998), yönetici işlev becerilerini kullanmayı gerektiren görevlerin üstesinden gelme konusunda zorluk yaşayan okul öncesi çocuklarının -özellikle de yüksek düzeyde inhibisyon kontrol becerisi gerektiren görevler- kandırma görevlerinde de zorluklar yaşadığını bulmuşlardır. Farklı çalışmalarda, inhibisyon kontrolü ve kandırma arasındaki bağlantının da orta çocukluk döneminde kuralları çiğnemenin inkârı ile (Talwar ve Lee, 2008); ergenlikte ise karmaşık yalanlar söyleme becerisi ile ilişkili olduğu sonuçlarına ulaşılmıştır (Evans ve Lee, 2011).

İnhibisyon kontrolünün yanı sıra, çocukların yalan söylemeleri ile çalışma belleği becerileri arasındaki bağlantılar da araştırılmıştır. Yalan söylemek için çalışma belleğinin aktif olması beklenebilir ancak bu yöndeki ilişkiyi gösteren araştırmalar sınırlı sayıdadır. Evans ve Lee (2011) çalışma belleğinin yalan söylemeyle bağlantılı olduğu görüşüne uygun bir sonuca ulaşırken; Talwar ve Lee (2008) ise çalışma belleği ile çocukların yalan söylemeleri arasında anlamlı bir ilişki bulamadıklarını rapor etmişlerdir. Prososyal yalan söyleme ile inhibisyon kontrolü ve çalışma belleği arasındaki bağlantıların da az sayıda çalışmada incelendiği görülmüştür. Örneğin, Williams ve arkadaşlarının (2016) çalışmasında, prososyal yalan söyleyen çocukların hem çalışma belleği hem de inhibisyon kontrol becerilerinin ölçümünde daha iyi performans gösterdikleri sonucuna ulaşılmıştır. Yine de, farklı yaş dönemlerinde bu konuda gerçekleştirilen araştırmaların sayısının az olması nedeniyle ilerleyen dönemlerde yeni çalışmalara ihtiyaç duyulduğu söylenebilir.

\section{c. Zekâ ve Yalan Söyleme Arasındaki Băğlantılar}

Bazı insanların diğerlerinden neden daha fazla yalan söylediğine ilişkin verilen cevaplardan bir diğeri de zekânın etkili olduğu yönündedir. Bu konuda ilk başta oluşan genel kanının, yalan söylemenin problem bir davranış olarak kabul edilmesi nedeniyle ortalama IQ altındaki insanların daha fazla yalan söylediği şeklinde olması muhtemeldir. Ancak genel bilişsel beceriler göz önünde bulundurulduğunda, bir yetişkin ya da çocuğun genel zekâsı ile yalan söyleme arasında nasıl bir ilişki olduğunu araştıran sınırlı sayıda çalışma mevcuttur. Bu çalışmalardan gelen birçok bulgu ise tutarsız ve çelişkili görünmektedir.

Bu konuda yürütülen ilk çalışmalardan birinde (Rutter, Tizard ve Whitmore, 1962; Akt. Ekman, 2016) 2-14 yaş arasındaki düşük IQ'lu çocukların üçte birinin yalan ve hileye başvurdukları, IQ yükseldikçe yalan söyleyen çocuk yüzdesinin azaldığı görülmüştür. Ancak çalışma bulguları ve açıklamalar, zekânın yalan söylemeyle olan bağlantısı konusunda daha temkinli olunması gerektiğini açıkça ortaya 
koymaktadır. Bu değişkenlerin bağlantılarının incelendiği bazı çalışmalarda, çocukların dürüstlüğü ile yüksek zekâya sahip olmaları arasında pozitif ilişki görülürken (Rutter, 1967), bazı çalışmalarda zekâ ve yalan söyleme davranışları arasında negatif yönde ilişki bildirilmiştir (Shepard, Oppenheim ve Mitchell, 1971). Hatta bazı araştırmalarda ise zekâ ve yalan söyleme arasında herhangi bir ilişki olmadığı da rapor edilmiştir (McFarlane, Allen ve Honzik, 1962). Ancak bu çalışmalarda çocukların yalan söyleme ve kandırma davranışlarının yetişkinler tarafından değerlendirilmiş olması bir eksiklik olarak göze çarpmaktadır. Aynı zamanda dürüstlük ve zekâ olumlu bir yöne işaret ettiği için, olası önyargıları akla getirebilir. Daha yakın zamanda yapılan ve yalan davranışının görev üzerinden değerlendirilmiş olduğu bir çalışmada (Lewis ve Crossman, 2003), yüksek IQ’ya sahip olan çocukların daha fazla olumsuz yalan söyledikleri sonucuna ulaşılmıştır.

Zeki çocukların daha az hile yaptıklarına ilişkin ağırlık kazanan bulguların üzerine, Ekman (2016), bu tür çocukların kandırmaya ihtiyaç duymayabilecekleri şeklinde bir açıklama yapmanın doğru olmayacağını, sadece zeki çocukların başarı sağlamak için yalana başvurma ihtimallerinin daha az olduğunu ifade etmektedir. Buna göre daha zeki olan çocuklarda, yalan söyleme ihtiyacı daha az görülmekle birlikte, gerekli durumlarda kolaylıkla daha profesyonel yalanlara rastlanabilir. Stouthamer-Loeber (1986), bu konuda zeki çocukların daha iyi yalancı ve hileci olabileceklerini ifade etmektedir. Araştırmacıya göre bu tür çocuklar, yakalanması çok daha zor olan, iyi kurgulanmış yalanlar söyleyebilirler. Benzer bir görüşü dile getiren Ekman (2016) da, ebeveynleri tarafından bask1 altında olan son derece zeki çocukların, olumsuz durumlardan kurtulabileceklerini anladıkları takdirde ortalama çocuklardan daha fazla yalan söylemelerinin olası olduğunu dile getirmiştir.

Açıklamalar ve çalışma bulguları bir arada değerlendirildiğinde bu tür çalışmaların eksikliği göze çarpmaktadır. Ayrıca, zekânın zihin kuramı ve yönetici işlevler bileşenleri gibi diğer bilişsel becerilerle ilişkili olabileceği göz önünde bulundurulursa bu konuda kesin bir çıkarımda bulunmak da zorlaşmaktadır.

\section{Sosyal Etmenler}

Çocukların ebeveynler, öğretmenler, medya ve diğer kültürel etmenlerin aracıllğıyla sosyalleştiği ve bu etmenlerin çocukların gelişimleri üzerinde birçok açıdan etkili olduğu açıktır. Aslında yalan söyleme davranışlarının da çeşitli sosyalleşme süreçlerinden etkilendiğini söylemek mümkündür. Ancak bireysel farklılıklara ilişkin yürütülen mevcut çalışmaların birçoğu bilişsel faktörlere odaklanırken, sosyal etmenlerin ihmal edildiği görülmektedir. Derlemenin bir sonraki bölümünde, sosyal etmenlerin yalan söyleme davranışları ile olan bağlantılarına değinilmektedir.

\section{a. Ebeveynlik ve Yalan Söyleme Arasındaki Băglantılar}

Çocukların yaşamlarının ilk dönemlerinde kendileri üzerinde en çok etkisi olan kişiler hiç şüphesiz ki ebeveynleridir. Birçok ebeveynin, çocuklarını yetiştirirken onların nasıl kimseler olacakları, ahlaki değer ve davranışlarının ne yönde gelişmesi gerektiği gibi çeşitli beklentileri vardır. Çocuklarını bazı hedefler doğrultusunda yetiştirmek için çeşitli stratejiler denerler; çocuklarının davranışını ödüllendirir veya cezalandırırlar, onlara model olurlar, kendi değer ve inançlarını onlara anlatırlar ve hatta çocuklarının çevrelerini bile bu hedeflerini destekleyecek şekilde düzenlerler.

Her ne kadar toplumlarda yalan söylemek kötü bir davranış olarak görülse bile, her durumda koşulsuz şartsız doğruların söylenemeyebileceği yetişkinler tarafından çocuklara aktarılmaktadır. Dolayısıyla ebeveynlerin, çocuklarının yalan söyleme davranışı üzerinde etkili olmaları muhtemeldir ki araştırmalarda da bu beklenti desteklenmektedir. Örneğin, Heyman, Luu ve Lee (2009), ebeveynlerin çocuklarına bazı durumlarda yalan söyleyebildiklerini ve böylece çocukların yalan söyleme davranışlarının pekiştiğini ifade etmektedirler. Literatüre "yalan söyleyerek ebeveynlik yapma" terimini sunan araştırmacılar, ebeveynlerin hem çocuklarına yalan söyleyerek hem de çocuklarının bilmesini istemedikleri konulardan kaçınarak çocuklarının yalan söyleme davranışlarını etkilediklerini belirtmektedir.

Yıılar boyunca gelişim psikolojisi araştırmalarına konu olan ebeveynlik tutumları çalışmaları, çocuklara katı kurallar koyulan ve kendilerinden bu kurallara uyması beklenen otoriter ebeveynliğin, çocukların birçok davranış alanında sorun yaşamalarına neden olduğunu açı bir şekilde göstermektedir (Baumrind, 1991). Stouthamer-Loeber (1986) ebeveyn tutum ve stillerinin çocukların 
yalan söyleme davranışlarına etkisi konusunda, ebeveynin olumsuz denetim ve disiplin yöntemleri, ebeveyn reddi gibi faktörlerin çocuklarda karmaşık ve iyi kurgulanmış yalanları daha fazla beraberinde getirdiğini ifade etmektedir.

$\mathrm{Bu}$ açıklamalara paralel olarak, ebeveynlerin katı kurallar koyduğu ve fazla denetleyici olduğu ailelerde, çocukların daha fazla yalan söylediğine yönelik bulgular da mevcuttur (Jensen, Arnett, Feldman ve Cauffman, 2004). Çalışmada ortaya çıkan önemli bir sonuç, çocukların ebeveynlerinin kendi özerkliklerine saygı duymadıklarına inandıkları takdirde yalana başvurduklarının gözlenmesidir. Buna karşılık, birlikteliği ve destekleyiciliği önemseyen ailelere sahip olan çocukların yalana daha az başvurdukları görülmüştür. Jensen ve arkadaşları (2004) bu bulguları kontrol ve destekleyicilik arasındaki farktan kaynaklandığı, bir diğer ifadeyle çocukların ebeveynleriyle olan ilişkilerinde birbirlerine güven duydukça yalan söyleme sıklıklarının da azaldığı şeklinde yorumlamışlardır. Ma, Evans, Liu, Luo ve Xu (2015) tarafından yapılan yakın tarihli bir çalışmada, kontrolün fazla olduğu ebeveynlik tutumuna maruz kalan 3 yaşındaki çocukların olumsuz yalanlarının daha az olduğu bulunmuştur. Ancak bu ilişkide zihin kuramı becerilerinin aracı rolü olduğu görülmüştür. Diğer iki ebeveynlik türünde yer alan duygusal-sıcaklık ve ceza boyutunun ise yalan söyleme davranışlarıyla ile herhangi bir bağlantısı bulunamamıştır. Bütün bu çalışmaların sonuçları, ebeveynlik ve yalan söyleme davranışları arasındaki ilişki hakkında keşfedilmesi gereken birçok şey olduğunu ortaya koymaktadır.

Çocukların davranışlarını etkileyen sosyal faktörler arasında sadece ebeveyn tutumlarının olduğunu söylemek eksik kalacaktır. Anne ve çocuk arasındaki bağlanmanın da çocukların gelişimindeki etkisi yeterince açıktır. Her ne kadar bağlanma ve yalan söyleme davranışları konusunda çok az araştırma olmasına rağmen, bunlardan birinde yetişkinlerdeki güvensiz bağlanma ile dürüst olmayan davranışlar arasında bir ilişki bulunduğu dikkati çekmektedir (Gillath, Seko, Shaver ve Chun, 2010). Çalışmada, yetişkinlerdeki güvenli bağlanmanın, bir zekâ testinde hile yapma sıklığını azalttığı bulunmuştur. Kaygılı ve kaçınan bağlanma stillerinin aynı zamanda insanların kime yalan söylediği (yabancı, yakın arkadaş veya partner) ve yalanın türüyle (olumsuz, prososyal) de ilgili olduğu rapor edilmiştir (Ennis, Vrij ve Chance, 2008). Bu çalışmada kaygılı bağlanmada görülen artışın, yabancılara ve yakın arkadaşlara yalan söyleme davranışlarını artırdığ 1 görülmüştür. Kaçınan bağlanma stilinin ise romantik partnerlere yalan söyleme davranışını yordadığı bulunmuştur. Bulgular, güvenli bağlanan ebeveynlerin çocuklarında dürüstlüğü geliştirmelerinin daha olası olduğunu ve bunun muhtemelen çocuklarının davranışlarına da yansıyacağını göstermektedir.

Literatürde çocukların yalan söyleme davranışları ile ebeveyn çocuk ilişkisinin kalitesi arasındaki bağlantılar da ayrıca incelenen konulardandır. Örneğin, Finkenauer, Engels ve Meeus (2002), şefkatli ve karşılıklı iletişimin yaygın olduğu ailelerde büyüyen çocukların, bu hususlarda daha az duyarlı ailelerde büyüyen çocuklara kıyasla daha az yalan söylediklerini rapor etmişlerdir. Ebeveynler yalanı tespit ederlerse, çocuklarının onlara karşı dürüst olmayacaklarından korktukları için çocuklarıyla iletişim miktarının da düşmesinin muhtemel olduğunu söyleyen Engels, Finkenauer ve van Kooten (2006) bu gibi durumların ebeveyn-çocuk ilişkisi içinde yabancılaşmaya neden olabileceğini söylemişlerdir. Ayrıca çocukların sık sık yalan söylemelerinin ebeveynlerin ilişkide bir kontrol eksikliği yaşamalarına neden olduğu araştırmacılar tarafından rapor edilmiştir. Engels ve arkadaşları (2006), çocuğun sık sık yalan söylemesinin yetersiz ebeveynlikle ilişkili olduğunu ve ebeveynlerin çocuklarıyla kaliteli iletişim kurmaları gerektiğini belirtmişlerdir. Sonuç olarak, çocuğun sık sık yalan söyleme durumunun, ebeveyn-çocuk ilişkisinin kalitesinin yetersizliğiyle bağlantılı olduğu ve nihayetinde ebeveynin ebeveynlik becerilerini zayıflattığı gibi çocukların da özgüvenlerini zedeleyerek daha fazla yalan söylemelerine neden olabileceği söylenebilir.

Ancak araştırmacılar yalan söylemenin altında yatan motivasyonu sadece çocuğun etkilendiği ebeveynlik tarzına ve ailedeki etkileşime bağlama konusunda temkinli davranmışlardır. Bu durumun nedeni olarak yalan söyleme davranışlarının değerlendirilmesinde, tek soruluk ebeveyn ve öğretmen bildirimlerine bağlı kalınması gösterilebilir. $\mathrm{Bu}$ nedenle bulguları yorumlamada dikkatli olmak gerekebilir. Yine de, literatürde oluşan genel resim, olumsuz ebeveynlik stillerine maruz kalan çocukların çok yönlü kandırma stratejileri geliştirdikleri şeklindedir.

\section{b. Kültürel Etmenler ve Yalan Söyleme Arasındaki Bağlantılar}

Kültürler ahlaki ve sosyal açıdan kabul edilebilir davranışları düzenlemektedir. Çocuklar içinde yaşadıkları kültürün sosyal ve ahlaki sistemine bağlı kalarak neyin doğru neyin yanlış olduğunu 
öğrenecek şekilde sosyalleşmektedirler. Yalan söyleme davranışları kültürler arası çalışmalarda da yer edinmiştir ancak çalışmalarda genellikle farklı kültürlerden çocukların yalanı nasıl değerlendirdiklerine odaklanılmıştır. Henüz iki-üç yaşında olan çocuklarda kültürün tam olarak devrede olmaması, okullaşmayla birlikte bu tür etkilerin görünür hale gelmesi yalan söyleme davranışlarının ilk ortaya çıkışında kültürel etmenlere net bir şekilde atıfta bulunmayı zorlaştırmaktadır.

Lee (2013), kültürel etmenlerin yalan söyleme davranışlarıyla olan bağlantısı konusunda "konuşma eylem (speech-act) yaklaşımından" faydalanarak çocukların yalan söyleme davranışlarında iki önemli bileşene dikkat çekmektedir: bunlar "niyetlilik" ve "gelenekçilik"tir. Konuşma eylem yaklaşımına göre, sözlü ifadeler sadece belirli olayları tanımlamamakta aynı zamanda belirli sosyal işlevlere hizmet eden niyetli eylemler olarak kabul edilmektedir. Bu iki bileşenin aslında yalan söyleme davranışlarını etkileyen bilişsel ve kültürel yaklaşımla uyumlu olduğu ifade edilmektedir. Niyetliliğin zihin kuramı becerisinin gelişimiyle, gelenekçiliğin ise kültürel etkilerle bağlantılı olduğunu belirtmiştir. $\mathrm{Bu}$ yaklaşıma göre, belirli bir bağlam özelinde sosyal ve kültürel faktörlerin iletişime nasıl aracılık ettiği meselesi önemlidir. Bir diğer ifadeyle, gerçek olmayan ifade içinde bulunulan ortam için gerekli mi, bu ortamda naziklik mi yoksa bilginin doğruluğu mu ön planda tutulmalı gibi sorular devreye girmektedir. Yalan söyleme davranışlarının nasıl karşılandığı bağlama göre değişebileceği gibi farklı toplumsal etmenlerin çocukların yalana ilişkin düşüncelerini etkilemesi oldukça makuldür. Böylesi bir kültürel etkinin sosyal etkileşimlerde grup ve bireye verilen değerden kaynaklandığı düşünülebilir. Bireyciliktoplulukçuluk çerçevesinden bu konuya yaklaşıldığında, Hofstede (1980), bireycilikte toplumsal görevlerden ziyade bireyin kendi haklarının ön planda tutulduğunu, başkalarına bağlılık yerine kişisel özerkliğe değer verildiğini ve grubun uyumu ve amaçlarındansa bireyin kendi başarısının vurgulandığını ifade etmektedir. Toplulukçulukta ise bireyin kendisi ve yakınlarından ziyade toplumun amaçlarına önem verildiği ve kişisel başarıların yerine grup uyumunun önceliği vurgulanır. Her iki yönelim de toplumda birlikte görülebileceği için bu iki değerden sadece birinin bir toplumda gözleneceğini söylemek doğru olmayacaktır. Ancak olgulara verilen önem ve dikkatin kültürlere göre farklılaşacağı söylenebilir.

$\mathrm{Bu}$ gibi kültürel farklılıkların yalan söyleme davranışında etkili olabileceğini savunan bazı araştırmacılar toplulukçu bir ülke olan Çin ile bireyci olarak değerlendirilen Kanada'daki çocukları karşılaştırmak üzere bir dizi çalışma yürütmüşlerdir. Çocukların yalan ve doğruyu söyleme konusundaki ahlaki değerlendirmeleri üzerindeki kültürel ve sosyal bağlamın etkisini ilk araştıranlar arasında Lee, Cameron, Xu, Fu ve Board (1997) bulunmaktadır. Çinli ve Kanadalı çocuklardan, prososyal ve antisosyal ortamlarda yalan söyleme ve doğruyu söyleme davranışlarını değerlendirmeleri istendiğinde, alçakgönüllülük (yani kişisel başarılar / iyilikler hakkında övünmeyerek veya dışarıdan övgü isteyerek kendini yüceltmekten kaçınma) etkisinin öne çıktığı görülmüştür. Prososyal içerikli olduğunda, Çinli çocukların Kanadalı çocuklara göre yalan söyleme davranışını daha az olumsuz; doğruyu söyleme davranışını ise daha az olumlu şeklinde değerlendirdikleri görülmüştür. Her iki kültürde de, antisosyal içerikli durumlarda yalan söyleme davranışı olumsuz ve doğruyu söyleme olumlu olarak değerlendirilmiştir. Ayrıca araştırmacılar, çocuklar büyüdükçe alçakgönüllülük etkisinin daha da belirginleştiğini raporlamışlardır. Bu nedenle, iyi eylemleri için takdir gören bir birey yerine grup uyumluluğun sürdürülmesi, toplulukçu kültürlerde önemli bir değer olduğu söylenebilir.

Yine de bu tür çalışmaların odak noktası, yalanın çocuklar tarafından nasıl değerlendirildiği olduğunu tekrarlamak gerekir. Bu nedenle, ileride yapılacak araştırmalarda farklı yaş dönemlerindeki çocukların yalan söyleme davranışlarının ele alınmasının önemli olduğu söylenebilir.

\section{SONUÇ}

Tüm bu araştırmalar dâhilinde mevcut derleme çalışmasında, çocuklarda yalan söyleme davranışının gelişimsel süreçleri açıklanmaya çalışılmıştır. Ayrıca çocukların yalan söyleme davranışlarını etkileyen etmenlere de değinilmiştir. Bu bağlantılara yer verilirken literatürde en belirgin görünen değişkenler ele alınmıştır.

Ancak çocukların yalan söyleme davranışlarının hem mevcut derleme çalışmasında ele alınmayan hem de literatürde eksikliği görülen daha farklı etmenlerle olan bağlantısının incelenmesi gerektiği de düşünülmektedir. Örneğin, bunlardan biri çocukların okul öncesi dönemden itibaren içerisinde yer aldığı okullardır. Sosyalleşme süreçlerinde ebeveynin önemli rolü olduğu gibi çocukların erken yaşlardan itibaren dâhil olduğu okullar ve bu kurumlarda verilen eğitimler de çocukların yalan söyleme 
davranışlarını şekillendirmektedir. Aileden sonra çocuğun hayatına giren ve formal eğitimin ilk basamağını oluşturan okul öncesi eğitimde, çocuğun gelişimsel özellikleri dikkate alınarak oluşturulan programlar doğrultusunda ilkokula hazırlanması amaçlanır. Değerler eğitimi bu programın içerisinde yer alan önemli hedeflerden biridir. Değerler sosyal-duygusal yönden sağlıklı gelişimin önemli bir yardımcısı olarak görülmektedir. Değerlerin edinilmesinde okulun en uygun ortamlardan biri olduğu düşünülürse, eğitimin ilk aşamasında bazı temel değerlerin öğretilmesi daha da önem kazanmaktadır. $\mathrm{Bu}$ doğrultuda ülkemizde son yıllarda giderek önem kazanan okul öncesi değerler eğitimi çalışmalarında vurgulanan değerlerden biri doğruluk-dürüstlüktür. Benzer şekilde, bambaşka bir coğrafyada olan Çinli çocuklara da hükümet tarafından okul öncesi dönemden itibaren toplulukçuluk ve vatanseverliğin yanı sıra dürüstlük ve alçakgönüllü olma gibi değerler aktarılmaktadır (Price, 1992). Hatta çocukların dönem sonu davranışlarının değerlendirilmesinde bu değerler esas alınmaktadır. Ancak erken çocukluk döneminde dürüstlük, yalan söylememe gibi değerlerin çocuklara verilmesinin yalan söyleme davranışlarındaki etkisi yeterince açık değildir. Bu nedenle, ileride deneysel yöntemler tasarlanarak bu değerlerin yalan söyleme davranışlarına olan etkilerini incelemek önemli görünmektedir.

Çocukluk döneminde yalan söyleme davranışlarıyla bağlantıları bakımından literatürde eksik kalan noktalardan bir diğeri de çocukların bireysel özellikleri ve farklılıklarıdır. Aslında bazı çalışmalarda bireysel farklılıklar incelenmesine rağmen, bunların çoğunun yalanı tespit etme veya yalanın nasıl değerlendirildiğine odaklandığı ve genellikle yetişkin örnekleminde gerçekleştirildiği görülmektedir (Bond, Malloy ve Arias, 2005; McLeod ve Genereux, 2008; Porter, Campbell, Stapleton ve Birt, 2002). Dolayısıyla yalan söyleme davranışları ve kişilik özellikleri arasındaki ilişkiler konusunu çocukluk dönemindeki katılımcılarla araştıran çalışmalara ihtiyaç olduğunu söylemek mümkündür.

Bununla birlikte, literatürde sadece yalan söyleme davranışlarının değil, yalana ilişkin yargıların, kimlere yalan söylendiği ve hangi motivasyonlarla yalana başvurulduğu gibi konuların incelendiği görülmektedir (Lee vd., 1997). Bu çalışmaların ise genellikle ergenlik ve yetişkinlik dönemindeki katılımcı gruplarında ele alındığı göze çarpmaktadır (McLeod ve Genereux, 2008). Aslında okul öncesi dönemdeki çocukların hangi motivasyonlarla yalan söylediklerini incelemek literatüre katkı sağlayabilir. Bu konuda daha önce yapılan açıklamaların ebeveyn ve öğretmen bildirimlerine dayandığı göz önüne alınırsa (Ekman, 2016), bu amacı gerçekleştirebilmek için yeni ölçme yöntemleri ve görevlerin tasarlanmasına ihtiyaç duyulduğu söylenebilir.

Benzer şekilde, ileri yaş gruplarında irdelenen bir diğer konu yalanın nasıl değerlendirildiği ve hangi durumlarda uygun bulunduğu meselesidir. Çalışmalarda genellikle yalan söyleme davranışının kabul edilebilirliğine yönelik ikilem yaratacak senaryolar kullanılarak yalanın değerlendirilmesi ölçülmektedir (Lee vd., 1997). Belki de okul öncesi dönem çocukları için bu hikâyeleri çocuklara uygun resim kartları ya da kısa animasyonlara uyarlayarak erken yaşlardaki çocukların yalana ilişkin yargılarını incelemek ve daha küçük yaşlarda yalanın uygunluğunu etkileyen faktörleri araştırmak mümkün olabilir.

Sonuç olarak, mevcut çalışmada insan sosyalliğinin önemli bir parçası olan yalan söyleme davranışlarının çocukluk dönemindeki gelişimi ve bilişsel-sosyal etmenlerle olan bağlantıları ele alınmıştır. Bununla birlikte, ileride yapılabilecek araştırmalara yönelik eksik kalan noktalara değinilmiştir. Türkiye'de çocukların yalan söyleme davranışlarının incelendiği çalışmaların neredeyse yok denecek kadar az olması nedeniyle, hem gelişimsel süreçlerine yönelik araştırmaların hem de yukarıda sunulan sınırlılıkların giderilmesine yönelik araştırmaların ülkemizde gerçekleştirilmesinin önemli olduğu değerlendirilmektedir. 
Aydın, M. Ş. (2020). Yalanın Renkleri: Yalanın tanımlanması ve türleri üzerine bir değerlendirme. Uluslararası Sosyal Araştırmalar Dergisi, 13(69), 712-720.

Aydın, M. Ş. (2021). 29-72 aylık çocukların olumsuz ve prososyal yalan söyleme davranışlarının incelenmesi. Erken Çocukluk Çalışmaları Dergisi, 5(1), 92-108.

Baumrind, D. (1991). The influence of parenting on style of adolescent competence and substance use. Journal of Early Adolescence, 11, 56-95.

Bond, G. D., Malloy, D. M., \& Arias, E. A. (2005). Lie-based decision making in prison. Communication Reports, 18(1), 9-19.

Carlson, S. M., Moses, L. J., \& Hix, H. R. (1998). The role of inhibitory processes in young children's difficulties with deception and false belief. Child Development, 69(3), 672-691.

Cole, P. M. (1986). Children's spontaneous control of facial expression. Child Development, 57, 1309- 1321.

DePaulo, B. M., Kashy, D. A., Kirkendol, S. E., Wyer, M. M., \& Epstein, J. A. (1996). Lying in everyday life. Journal of Personality and Social Psychology, 70, 979-995.

Ekman, P. (2016). Çocuklar Neden Yalan Söyler?. Yakamoz Yayınları.

Engels, R. C. M. E., Finkenauer, C., \& van Kooten, D. C. (2006). Lying behavior, family functioning and adjustment in early adolescence. Journal of Youth \& Adolescence, 35(6), 949-958.

Ennis, E., Vrij, A., \& Chance, C. (2008). Individual differences and lying in everyday life. Journal of Social and Personal Relationships, 25, 105-118.

Evans, A. D., \& Lee, K. (2011). Verbal deception from late childhood to middle adolescence and its relation to executive functioning skills. Developmental Psychology, 47(4), 1108-1116.

Evans, A. D., \& Lee, K. (2013). Emergence of lying in very young children. Developmental Psychology, 49(10), 1958-1963.

Evans, A. D., Xu, F., \& Lee, K. (2011). When all signs point to you: lies told in the face of evidence. Developmental Psychology, 47(1), 39-49.

Finkenauer, C., Engels, R. C., \& Meeus, W. (2002). Keeping secrets from parents: Advantages and disadvantages of secrecy in adolescence. Journal of Youth \& Adolescence, 31(2), 123136.

Gillath, O., Sesko, A. K., Shaver, P. R., \& Chun, D. S. (2010). Attachment, authenticity, and honesty: Dispositional and experimentally induced security can reduce self- and other deception. Journal of Personality and Social Psychology, 98, 841-855.

Gnepp, J., \& Hess, D. L. (1986). Children's understanding of verbal and facial display rules. Developmental Psychology, 22(1), 103-108.

Goffman, E. (1967). Interpersonal ritual: Essays on face-to-face behavior. New York: Pantheon Books.

Gombos, V. A. (2006). The cognition of deception: The role of executive processes in producing lies. Genetic, Social, and General Psychology Monographs, 132(3), 197-214.

Heyman, G. D., Luu, D. H., \& Lee, K. (2009). Parenting by lying. Journal of Moral Education, 38(3), 353-369.

Hofstede, G. (1980). Culture's consequence. Beverly Hills CA: Sage.

Hughes, C., Graham, A., \& Grayson, A. (2004). Executive function in childhood: Development and disorder. Cognitive and Language Development in Children, 205-230.

Jensen, L. A., Arnett, J. J., Feldman, S. S., \& Cauffman, E. (2004). The right to do wrong: Lying to parents among adolescents and emerging adults. Journal of Youth and Adolescence, $33(2), 101-112$.

Lavoie, J., Leduc, K., Arruda, C., Crossman, A. M., \& Talwar, V. (2017). Developmental profiles of children's spontaneous lie-telling behavior. Cognitive Development, 41, 33-45.

Lee, K. (2013). Little liars: Development of verbal deception in children. Child Development Perspectives, 7(2), 91-96.

Lee, K., Cameron, C.A., Xu, F., Fu, G., \& Board, J. (1997). Chinese and Canadian children's evaluations of lying and truth telling: Similarities and differences in the context of proand antisocial behaviors. Child Development, 68(5), 924-934. 
Lewis, M., \& Crossman, A. M. (2003). Smooth criminals? Detecting children's lies. In V. Talwar \& T. Lyon (Chairs), Veracity of children: The psychological and legal implications. Symposium conducted at the American Psychological Association convention, Toronto, Canada.

Lewis, M., Sullivan, M. W., Stanger, C., \& Weiss, M. (1989). Self development and selfconscious emotions. Child Development, 60, 146-156.

Ma, F., Evans, A. D., Liu, Y., Luo, X., \& Xu, F. (2015). To lie or not to lie? The influence of parenting and theory-of-mind understanding on three-year-old children's honesty. Journal of Moral Education, 44, 198-212.

McFarlane, J. W., Allen, L., \& Honzik, M. P. (1962). A developmental study of the behaviour problems of normal children between twenty-one months and fourteen years. Berkeley, CA: University of California Press.

McLeod, B. A., \& Genereux, R. L. (2008). Predicting the acceptability and likelihood of lying: The interaction of personality with type of lie. Personality and Individual Differences, 45(7), 591-596.

Miyake, A., Friedman, N. P., Emerson, M. J., Witzki, A. H., Howerter, A., \& Wager, T. D. (2000). The unity and diversity of executive functions and their contributions to complex "frontal lobe" tasks: A latent variable analysis. Cognitive Psychology, 41(1), 49-100.

Moll, H., \& Tomasello, M. (2007). How 14- and 18-month-olds know what others have experienced. Developmental Psychology, 43(2), 309-317.

Newton, P., Reddy, V., \& Bull, R. (2000). Children's everyday deception and performance on false-belief tasks. British Journal of Developmental Psychology, 18(2), 297-317.

Polak, A., \& Harris, P. L. (1999). Deception by young children following noncompliance. Developmental Psychology, 35, 561-568.

Porter, S., Campbell, M. A., Stapleton, J., \& Birt, A. R. (2002). The influence of judge, target, and stimulus characteristics on the accuracy of detecting deceit. Canadian Journal of Behavioural Science, 34(3), 172-188.

Price, R. (1992). Moral-political education and modernization. In T. Hayhoe (Ed.), Education and modernization: The Chinese experience (pp. 211-238). New York: Pergamon.

Ruffman, T., Olson, D. R., Ash, T., \& Keenan, T. (1993). The ABCs of deception: Do young children understand deception in the same way as adults?. Developmental Psychology, 29(1), 74-87.

Rutter, M. (1967). A children's behavior questionnaire for completion by teachers: Preliminary findings. Journal of Child Psychology and Psychiatry, 8, 1-11.

Saarni, C. (1984). An observational study of children's attempts to monitor their expressive behavior. Child Development, 55, 1504- 1513.

Serota, K. B., Levine, T. R., \& Boster, F. J. (2010). The prevalence of lying in America: Three studies of self-reported lies. Human Communication Research, 36, 2-25.

Shepherd, M., Oppenheim, B., \& Mitchell, S. (1971). Childhood behavior and mental health. London: University of London Press.

Stouthamer-Loeber, M. (1986). Lying as a problem behavior in children: A review. Clinical Psychology Review, 6(4), 267-289.

Talwar, V., \& Crossman, A. (2011). From little white lies to filthy liars: The evolution of honesty and deception in young children. Advances in Child Development and Behavior, 40, 139179.

Talwar, V., Gordon, H., \& Lee, K. (2007). Lying in the elementary school: Verbal deception and its relation to second-order belief understanding. Developmental Psychology, 43, 804-810.

Talwar, V., \& Lee, K. (2002a). Development of lying to conceal a transgression: Children's control of expressive behavior during verbal deception. International Journal of Behavioral Development, 26, 436-444.

Talwar, V., \& Lee, K. (2002b). Emergence of white-lie telling in children between 3 and 7 years of age. Merrill-Palmer Quarterly, 48, 160-181.

Talwar, V., \& Lee, K. (2008). Social and cognitive correlates of children's lying behavior. Child Development, 79(4), 866-881. 
Talwar, V., Murphy, S. M., \& Lee, K. (2007). White lie-telling in children for politeness purposes. International Journal of Behavioral Development, 31(1), 1-11.

Wellman, H. M. (1990). The child's theory of mind. Cambridge, MA: MIT Press, A Bradford Book.

Wellman, H. M., Cross, D., \& Watson, J. (2001). Meta-analysis of theory-of-mind development: The truth about false belief. Child Development, 72(3), 655-684.

Williams, S., Moore, K., Crossman, A. M., \& Talwar, V. (2016). The role of executive functions and theory of mind in children's prosocial lie-telling. Journal of Experimental Child Psychology, 141, 256-266.

Wilson, A. E., Smith, M. D., \& Ross, H. S. (2003). The nature and effects of young children's lies. Social Development, 12(1), 21-40. 